\section{ТУВИНСКАЯ МУЗЫКА И WORLD MUSIC}

\section{TUVAN MUSIC AND WORLD MUSIC}

\author{
Максим Шапошников \\ Независимый автор, \\ Нидерланды
}

\author{
Maxim V. Shaposhnikov \\ Independent author, \\ The Netherlands
}

В эссе представлены авторские наблюдения о процессе вхождения тувинской музыки в World Music - нишу мировой музыкальной культуры, в которой представлены этнические музыкальные традиции. Автор был свидетелем пробуждения интереса к традиционной музыкальной культуре в Туве и России, а также процесса глобализации тувинской музыки. Он ставит цель осмыслить эти перемены и выяснить, как они повлияли на саму традиционную музыку, на хоомей.

В конце советского времени традиционная музыка в Туве, как и во многих республиках страны, была как бы законсервирована. В период перестройки и процесса национального возрождения традиционность стала восстребованной. В Туве стали проводиться симпозиумы, фестивали, на которых самодеятельные исполнители выступали наравне с профессиональными. Особым почетом пользовались старые мастера хоомея. Ученые активно обсуждали происхождение, роль хоомея и его жанры.

Рыночный интерес к хоомею пришел извне. В конце 1980-х г2. американским ученым и продюсером Т.Левиным впервые были проведены полевые записи хоомейжи для выпуска диска. Был создан этнографический ансамбль «Тыва». Его участники впоследствии образовали свои музыкальные группь. Музыкальные программы составлялись по принципу этнографического дивертисмента, в тот период востребованная форма проведения концертов в

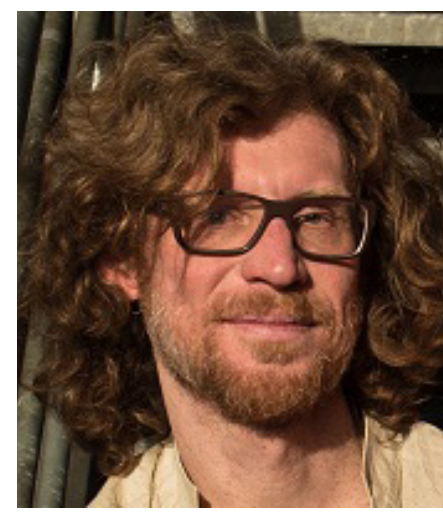

The essay presents the author's observations about the ingression of Tuvan music into the World Music - a niche of world musical culture covering ethnical music traditions. The author has witnessed the rise of interest to traditional musical culture of Tuva and Russia as well as globalization of Tuvan music. He is endeavoring to interpret these changes and reveal their affect on traditional music and xöomei. In the late Soviet period, traditional music in Tuva, like in many republics of the Union, has been as if put on hold. During the Perestroika and national revival processes, traditionalism became of high demand. Symposia and festivals started off in Tuva where amateur participants took the same stage with professionals. Special honor was paid to old masters of xöömei. Scholars started engaging in discussions about the origins and a role of xöomei and its genres.

Xöömei attracted a good deal of market interest from outside Russia. In the late 1980s American scientist and producer T.Levin made first field records of xöömei to be released on a disk. Ethnographic

Шапошников Максим Владимирович - независимый автор, музыкальный продюсер, звукохудожник, редактор отдела World Music на радиостанции Concertzender, г. Утрехт, Нидерланды. Эл. адрес: chapochnikov@gmail.com

Chaposhnikov Maxim Vladimirovich, Independent author, music producer, sound artist, editor of World Music section at Concertzender radio, Utrecht, The Netherlands.E-mail: chapochnikov@gmail.com 
самой Туве и за ее пределами. Начались выпуски дисков, гастроли тувинских исполнителей за границей. Резкий рост интереса к феномену World Music ознаменовался знаковым интересом $к$ феномену горлового пения и обертоновой музыки и развитие тувинской музыки с этого времени стало тесно связано с западным музыкальным рынком. Автор прослеживает особенности таких групп, как «Хун-Хурту», «Ят-ха» и др., $и$ отмечает, что ценность тувинской музыки не столько в звездах, покоривщих небосклон западного рынка, сколько в образовании стабильного сообщества людей, вдохновленных этой музыкой и культурой, ищущих новые пути эстетического и духовного мировосприятия.

Сегодня Тува имеет свои рок-группы, авангардные, женские и т. д. Горловое пение стало востребованным видом вокального искусства. Тувинская музыка привлекла сотни тысяч поклонников по всему миру. Распространение звуконосителей, в особенности тувинской музыки, позволило музыкантам Саяно-Алтая и Центральной Азии заново открыть многие жанры собственной традиции.

С начала 1990-х годов тувинская музыка ворвалась в мировое сознание наподобие монгольского нашествия. Очевиден глобальный успех тувинской музыки на мировом музыкальном рынке. Но неизбежен процесс нормализации восприятия тувинской музыки внешним миром.

Ключевые слова: World Music; тувинская музыка; Тува; тувинцы; хоомей; горловое пение; музыкальный рынок; Ооржак Хунаштар-оол; «Тыва»; T. Левин; этномузыковедение; «Хун-Хурту»; Кайгал-оол Ховалыг; Альберт Кувезин; «Ят-Ха» ensemble "Tuva" was established. Later, members of "Tuva" started their own musical bands. Musical programs were compiled as an ethnographic variety show - a principle that the public has been seeking for both in Tuva and abroad. Disks were realeased and artists started active touring in foreign countries. Boosting interest in World Music was marked with hallmark attention to the phenomenon of throat-singing and overtone music, and further evolution of Tuvan music has since been tightly linked to Western musical market. The author traces the peculiarities of such bands as "Huun Huur Tu", "Yat-Kha", etc. and remarks that the value of Tuvan music is not only in star performers shining on the Western skies, but in the rise of a stable community of people inspired by Tuvan music and culture, and seeking new ways of aesthetic and spiritual perception of the world.

Tuva now has its rock, as well as avant-garde, women bands, etc. Throat-singing became a popular type of vocal arts. Tuvan music attracts hundreds of thousands of fans around the world. Circulation of media, especially with Tuvan music, allowed musicians of Sayan-Altai region and Central Asia to rediscover many of their own genres.

Thus, Tuvan music burst into the world like a Mongol invasion in early 1990s. Global success of Tuvan music on the world music market is obvious. But the process of normalization of Tuvan music perception by the outer world is inevitable.

Keywords: World Music; Tuvan music; Tuva; Tuvans; khoomei; throat-singing; musical market; Oorzhak Khunashtar-ool; "Tyva"; T. Levin; ethnomusicology; "Huun Huur Tu"; Kaigal-ool Khovalyg; Albert Kuvezin; "Yat-Kha"

\section{Введение}

В конце 1970-х - начале 1980-х я еще учился в уральской школе и увлекался полузапретной тогда западной поп и экспериментальной музыкой. Поскольку западную музыку находить удавалось редко, в основном на черном рынке, мы с братом удовлетворяли музыкальный «голод» походами в городскую библиотеку в поисках альтернатив. Пластинки иногда попадались странные, вроде «Голоса Рыб» или «Аутогенная Тренировка». Одна такая «странная» пластинка оставила мощное впечатление и во многом определила мои интересы в мире музыки на всю жизнь.

Неописуемый песочный утробный голос выводил неведомые слова, переходящие в свист турбулентной флейты, похожий на звон проводов электропередач. Это звучало как голос, но не человеческий. Какая-то особая сила ис- 
ходила из этой записи. Сила, вызывающая приступы радости и восхищения. Локализовать происхождение записи по «яблоку» пластинки не удалось. Слова «тувинская музыка» ни о чем не говорили, а имя Ооржак Хунаштаар-оол было уж совсем сказочным. Найденные волшебным образом в собственной коллекции две марки с латинской надписью TOUVA совсем сбили с толку. Казалось, эта страна существовала где-то в другом измерении, но не на карте мира. В списке стран ее не было.

Пластинка была прослушана сотни раз и даже была использована нами в песне-коллаже группы «Братья По Разуму».

Когда я летел в Кызыл в 1991 г. на фестиваль хоомея, мне и в голову не приходила мысль, что я пожму руку человеку по имени Хунаштаар-оол и даже смогу услышать живьем хорошо знакомый мне в записи голос. Также не приходила в голову мысль, что через пару месяцев СССР не станет и мир войдет в новую эпоху, несущую в себе радикальные перемены даже в такой удаленной от всего «стране», как Тува. Более того, Тува подверглась переменам своим особенным, как никакое другое место в СССР.

В этой статье мы попробуем уловить смысл этих перемен и выяснить как они повлияли на такой, казалось бы, непоколебимый феномен тувинской культуры, как традиционая музыка, в первую очередь на примере хоомея.

Как эпоха перестройки и последующей глобализации изменила роль хоомея, манеру и контекст его исполнения?

Замечу, что здесь будет представлен вгляд со стороны, хотя и взгляд человека далеко не чужого тувинскому миру и, по-своему, активно участовашего в глобализации хоомея с самого начала 1990-х.

\section{Советское наследие}

В общих чертах обрисуем ситуацию, в которой находилась традиционная музыка малых народов СССР.

В региональных столицах при филармониях существовали отделения национальной музыки и танца, в которых работали профессиональные артисты с соответствующим образованием. Также существовали методические центры по изучению фольклора и разработке методичек для домов культуры. Эти центры занимались всем, что касалось народного творчества - музыкой, танцем, костюмами, рукоделием и прикладным искусством. Здесь тоже работали профессионалы, но их работа была уже рассчитана на художественную самодеятельность в районах. По методичкам и предписаниям этих центров дома культуры на местах строили свои программы.

Подавляющее большинство носителей традиционной культуры, исполнителей музыки в Туве, как и в других советских провинциях, не были профес124 
сионалами в общепринятом понимании. Они ходили на работу и получали зарплату не в учреждениях культуры, а в колхозах и совхозах, где они были трактористами, чабанами, учителями, медработниками, ветеринарами и т. д. Это не говорило о профессиональном уровне исполнителей. Например, тот самый Ооржак Хунаштаар-оол, будучи простым чабаном без формального музыкального образования, был удостоен выпуска сольной пластинки на фирме «Мелодия». Его репертуар входил во многие сборные диски, его исполнение песни «Река Алаш» получило специальные призы на престижных конкурсах. Не каждый профессиональный артист удостаивался такой чести в СССР. При этом музыка не стала для Хунаштар-оола источником профессионального дохода. Будучи достоянием и гордостью своего народа, он был наравне со всеми, довольствуясь почетом и вниманием.

Важно заметить, что представители советской культурной интеллигенции как в центре так и на местах относились к народному творчеству снисходительно и свысока. Я часто наталкивался на легкую стыдливость со стороны работников министерств или официальных учреждений по отношению к фольклору и к носителям, которым была, по их мнению, присуща нецивилизованность, недостаток образования, непредставительность, отсталость и т. п. Официальным лицам тогда не приходило в голову, что именно то, что называют нецивилизованностью - и есть главное богатство. Ориентиром была Москва и европейское искусство, и институтам, занимавшимся народным творчеством, отводилась третьестепенная роль после классики, джаза и других жанров.

В разные периоды советского времени традиционное искусство подвергалось нападкам со стороны идеологических институтов, которые могли обвинить тот или иной жанр или определенных исполнителей в проявлениях национализма или религиозного мракобесия. В Туве под опалу попадали песни, не соответствущие советской идеологии, а также контексты их исполнения, игра на хомусе и весь пласт шаманской культуры. При этом традиционная музыка адаптировалась к требованиям новой жизни: воспевание советских идеалов, аранжировка традиционного материала и переделка инструментария производились в соответствии с предписаниями министерства культуры. Эти действия привели к появлению официального фольклора, который демонстрировался как достижение. Но, поскольку, особенно в позднем СССР, такие проекты проводились формально, для галочки в соответствии с мандатом, то и корневой фольклор имел право на существование, если он не выходил за рамки идеологических табу.

Советская система, хотя и подвергла традиционную музыку давлению идеологии, при этом законсервировала ее в определенном безвременном состоянии, в котором традиционная музыка может пребывать на протяжении долгого времени, сохраняя в себе формулу выражения народного духа под маской внешнего послушания идеологии. 
С другой стороны, надо отдать должное факту, что в СССР была проведена обширная работа по исследованию тувинского фольклора (А. В. Анохин, А.Н.Аксенов, издания музыки на грампластинках и пр. пр.). Эти работы абсолютно бесценны сегодня для понимания ближайшего прошлого тувинской музыкальной культуры и тувинской культуры вообще. Ведь музыка Тувы непосредственно связана с образом жизни кочевника.

Несмотря на скромное освещение хоомея и традиционной музыки в советских тувинских СМИ, они пользовались в народе большой популярностью. Копии записей распространялись, насколько позволяла ситуация с бытовыми приборами. Например, записи Ойдупы, в то время persona non grata, можно было обнаружить на кассетах во многих домах еще задолго до наполнения музыкального рынка коммерчески размноженными звуконосителями и формального «отпущения» грехов певца.

Как в живом исполнении хоомея, так и в потреблении звуконосителей в тот период практически отсутствовала подоплека получения материальной выгоды. Ангажированные концерты, заказные стилизованные гимны партии были данью идеологии и власти. Лишь единицы имели от этого личную выгоду, и то незначительную. Традиционная музыка звучала от души и интерес к ней не подогревался идеей о том, что «американцы это любят».

Музыкальный рынок в Туве практически отсутствовал. Официальные издания пластинок и кассет были недоступны, радио и телевидение редко передавали традиционную музыку. Методички по развитию традиционной культуры были насквозь пропитаны идеологией. Тем не менее «устаревшие и отсталые элементы досоветской жизни» находили свое воплощение в реконструкциях, стилизациях и концертных программах фольклорных ансамблей филармонии или домов культуры.

Здесь мы стали свидетелями контраста между идеологизированным профессиональным фольклором, который прошел строгую цензуру и адаптацию для концертного дивертисмента (часть массовой официальной культуры) и чисто народным стилем исполнения в регионах, который нам удалось услышать во время экспедиций по Туве.

Традиционная музыка в этот переходный период была как бы законсервирована, находилась в некотором естественном равновесии между идеологией и свободным самовыражением. К началу 1990-х годов музыкального рынка не было, но был рынок идеологический, в застойной форме.

\section{Реабилитация народных мастеров}

Иронией судьбы стал тот факт, что в период перестройки, политических и социальных перемен становления свободного рынка, политически активные круги в своей риторике стали опираться на самоопределение национальных 
групп. Они вынуждены были обратиться к этому «забитому, нецивильному, отсталому» слою носителей традиционного сознания и бережно сохраненные ими традиционные символы. Музыка играла здесь первостепенную роль.

К 1990-м годам о Туве в СССР знали, пожалуй, только соседи, относившиеся к тувинцам с осторожностью, если не боязнью. В самой республике можно было встретить редких туристов из России, поскольку Саяно-Алтай всегда был притягателен для любителей рафтинга и горнолазания. Тувинцы слыли лихими парнями, готовыми вступить в конфликт по любому поводу. Вечерний Кызыл погружался в кромешную тьму и улицы города пустели от горожан и приезжих, опасавшихся подвыпившей молодежи, группы которой соревновались друг с другом в хулиганской удалости. Иногда на улице появлялась милиция, которая слыла не менее удалой. В дневное время город был обычным неказистым советским городом, где люди спешили на работу и учебу и имели свои житейские радости.

Таким я увидел Кызыл в июне 1991 г., когда наша небольшая делегация, состоящая из музыкантов и художников из Москвы и Амстердама, прибыла на республиканский конкурс-фестиваль хоомея по приглашению журналиста и музыканта Откуна Достая и ученой, этномузыковеда Валентины Сузукей.

Сюда собрались представители художественной самодеятельности разных районов, а так же выступали профессиональные артисты и коллективы, такие как ансамбль «Саяны» и др. Кроме концертов в программе был также и симпозиум с научными докладами и обсуждениями. Уровень качества у профессионалов и самодеятельных исполнителей был довольно близок. Профессиональное исполнение отличалось чуть более сложной аранжировкой, сценической постановкой и разнообразием номеров. Номера профессионалов были отформатированы под концертные программы.

Большинство самодеятельных исполнителей выступало сольно, как собственно и положено у тувинцев-кочевников. Особым почетом пользовались старые мастера, которые исполняли свои коронные номера и стили пения, в которых они были исключительно сильны (Тумат Кара-оол, Монгуш Сундукай, Севек Алдын-оол, Геннадий Тумат и др.). Публика слушала шумно, но внимательно, поощряя возгласами удачные моменты и снисходительно аплодируя при слабых выступлениях. Певцы представляли районные стили и свою личную трактовку. Различия между манерами исполнителей было довольно легко уловить, несмотря на то, что я был новичок в слушании горлового пения.

Фестиваль проходил с воодушевлением, обстановка была оживлённая и праздничная. Было такое ощущение, что хоомей придавал людям силы и уверенность в себе. С помощью В. Ю. Сузукей и Л. С. Артына мне удалось провести сессию записей коронных номеров отдельных исполнителей.

Во время записей я обратил внимание на разнообразие манеры исполнения, стилей и темперамента представителей разных районов (кожуунов) республики. 
Андрей Опей (Бай-Тайга) исполнял размеренно и как бы паря над степью, тогда как ребята из Сут-Холя пели бодро, в довольно быстром темпе, будто гоня коня галопом. Овюрцы пели особенно мощно хором и сольно (песню «Хандагайты» я тогда запомнил раз и навсегда), а аксакал Чульдум-оол мог усыпить слушателя своим бархатным мягким гипнотизирующим голосом и игрой на игиле.

Во время научной программы были любопытные обсуждения о происхождении хоомея, его роли и т. д. В своем докладе историк, шамановед М. Б. КенинЛопсан высказал по тем временам смелую идею о шаманских истоках хоомея, о связи с его древним мировоззрением тувинцев, об общении с духами тайги, что вызвало резкую критику со стороны искусствоведа 3. К. Кыргыс. Такая реакция была вполне естественной. Шаманизм в 1991 г. был еще 100\% табуирован. Тувинцам приходилось скрывать свои корни даже от самих себя, таковы были реалии Советского Союза. Во время симпозиума 1992-го года этот вопрос был уже обсуждаем, но в 1991 г. Монгуш Борахович был единственным, кто открыто отстаивал преемственность в тувинской культуре, хотя многие негласно поддерживали его. Думаю, сохранить эту преемственность помогло присущее тувинцам суеверное свойство не называть вещи своими именами.

1-й международный симпозиум «Хоомей» 1992-го года прошел в Кызыле уже в Музыкально-драматическом театре им. В. Кок-оола и стал масштабным историческим событием, привлекшим много иностранных гостей. Здесь окончательно утвердилась роль хоомея как символа тувинской культуры и начался процесс мощного экспорта хоомея за границу, с последующим вступлением тувинской музыки в международный музыкальный рынок и формированием новых стандартов его исполнения.

В 1992 г. мы продолжили сессии звукозаписи и общения с хоомейжи - исполнителями хоомея. С некоторыми из них мне удалось подружиться и провести много времени. Так, с Сундукаем мы вместе путешествовали по его родным местам, а Андрея Чульдум-оола мне удалось привезти в 1993-м году в Бенилюкс на серию концертов вместе с исполнителем на игиле и композитором Саая Бюрбю ${ }^{1}$. Тогда же я познакомился с Кайгал-оолом Ховалыгом, лидером группы «Хун-Хурту».

Здесь я опишу свои впечатления от этих первых встреч с некоторыми мастерами тувинской музыки.

Несмотря на то, что неопытному уху исполнение хоомея разными хоомейжи может показаться очень похожими, я обратил внимание на характерные черты у каждого опытного исполнителя. Это свой индивидуальный тембр голоса в определенном стиле пения.

${ }^{1}$ Фрагмент концерта Саая Бюрбю и Андрея Чульдум-оола в Амстердаме в 1993 году см.: https://youtu.be/wnkTWgUQ8_с 
К примеру, мастер каргыраа Федор Тау (из Тес-Хема) имел глубокий трубный голос. Находясь рядом с ним в гостиничной комнате, я чувствовал как все его тело вибрирует и мне даже казалось, что он излучает тепло. Назвать его пение

Aудиофайл № 1. Сундукай исполняет каргыраа, 1994. Запись Максима Шапошникова.
Audio file № 1. Sundukai performs the kargyraa, 1994. Field recording by Maxim
Chapochnikov.

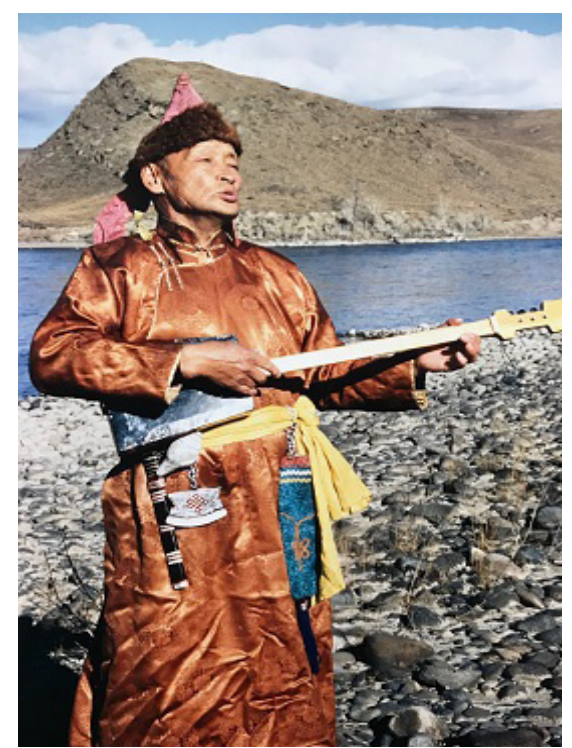

Фото 1. Сундукай на Енисее, 19932. Фото Максима Шапошникова. Foto 1. Sundukai on the Yenisei river, Kyzyl, 1993. Photo by Maxim Chapochnikov горловым было бы не совсем точно. Ритмика его не была ровной, но имела какой-то свой пульс, свой рисунок, обозначенный не только возможностями его дыхания.

Сундукай умел извлечь совсем необычные турбулентные звуки, тембры, которых я не слышал более ни у кого и никогда. Он умел на ходу сымпровизировать звук, обыграть его мелодикой и словами, что доставляло ему самому и его слушателям искреннюю радость. На фестивале в Кулун-Дужер, где я с ним познакомился и провел много времени, Сундукай водил меня по окрестному лесу, подражал звукам птиц и животных, и, несмотря на свой возраст, нырял в ледяную воду горного ручья. Он с удовольствием пел самые разные песни, рассказывал об их происхождении, приводил примеры из жизни. Сундукай слыл эксцентриком, это отражалось и в его манере пения. Его участие в официальных программах проводили с осторожностью, а на концерте на симпозиуме 1992

года его вывели со сцены...

Вообще некоторый эксцентризм или, если хотите, творческий индивидуализм, очень характерен для старых мастеров.

Чульдум-оол отличался спокойным и мягким характером, чувством юмора и всплесками мужской удали. Он мог бесконечно рассказывать байки и сказки. Однажды, будучи в хорошем настроении после коцерта в Амстердаме, он бодро зашагал по улице маршем, насвистывая мелодию сыгытом. Хотя его горловое пение уже и не об-

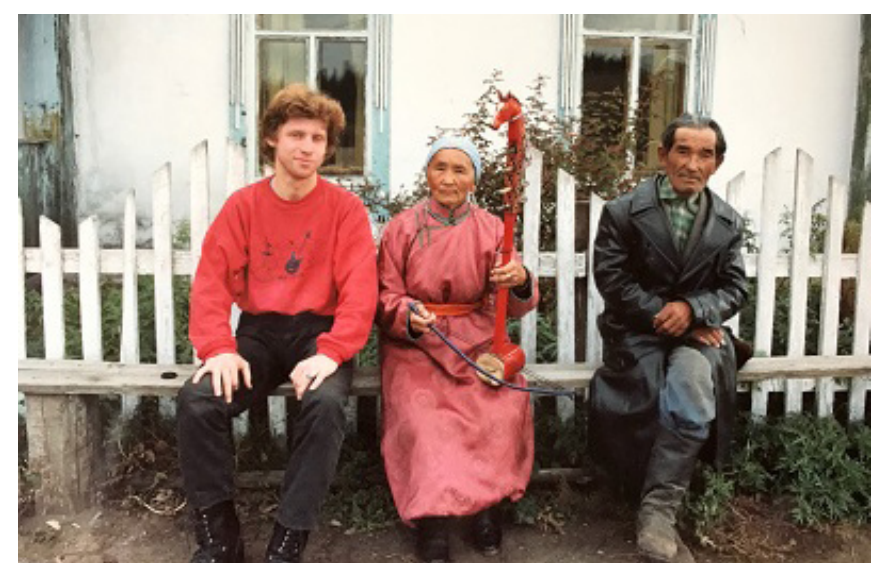

Фото. 2. Вместе с Андреем Чульдум-оолом (справа) в Арыг-Бажы, 1993. Фото Марка ван Тонгерена. Foto 2. Together with Andrei Tchuldum-ool (far right) in Aryg-Bazhy, 1993. Photo by Mark Van Tongeren. 


Аудиофайл 2. Балган Кужугет. Фрагмент шаманского обряда. 1992. Кара-Холь,
Бай-Тайга. Запись Максима Шапошникова.
Audio file № 2. Balgan Kuzhuget, An excerpt from a shamanic ceremony, 1992, Kara-
Khol, Bai-Taiga. Field recording by Maxim Chapochnikov.

ладало мощью молодых исполнителей, оно производило сильный эффект, особенно в комбинации с его игилом.

Встреча с Балганом Кужугетом в Бай-Тайге, по рекомендации Кенин-Лопсана, была тоже очень интересной. По утверждению самого Балгана, он не был шаманом, а лишь собирал шаманский фольклор. Он исполнил для нас реконструкцию шаманского камлания. Такого разнообразия рисунков игры на шаманском бубне, сочетания поэтических размеров и ритмических паттернов мне не доводилось слышать в Туве больше никогда.

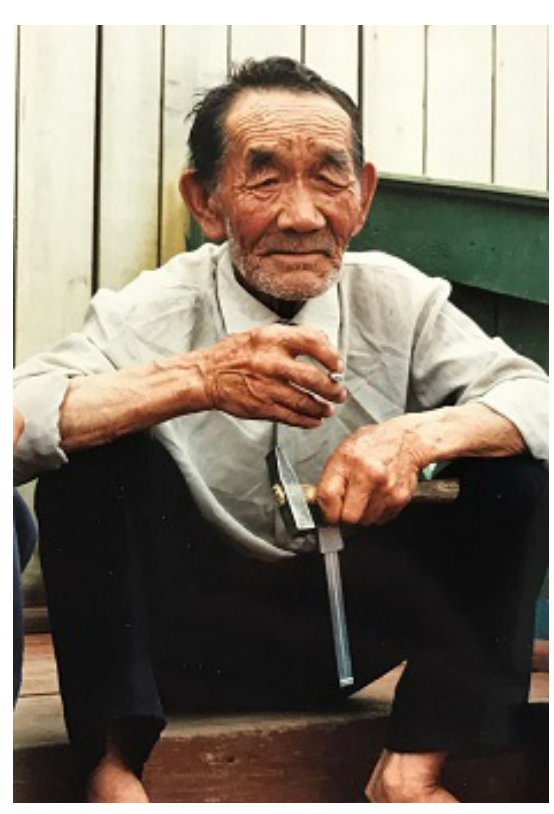

Фото 4. Идамчап Хомушку, непревзойденный мастер-изготовитель хомусов. Тээли, Бай-Таига. В знаменитых записях Хунаштар-Оола на фирме «Мелодия» использовался именно хомус Идамчапа. 1992. Фото Максима Шапошникова. Foto 4. Idamchap Khomushku, unexcelled master maker of khomus. 1992, Teeli, Bai-taiga. It was his mouth harp that was played by Kunashtar-ool in the well-known recordings on the Melodiya label.

Photo Maxim Chapochnikov.
Например, шаманские камлания Ай-Чурек и других неошаманов не отличались разнообразием ритмов бубна и были стандартно монотонны. Не говоря уже о более поздних групповых камла-

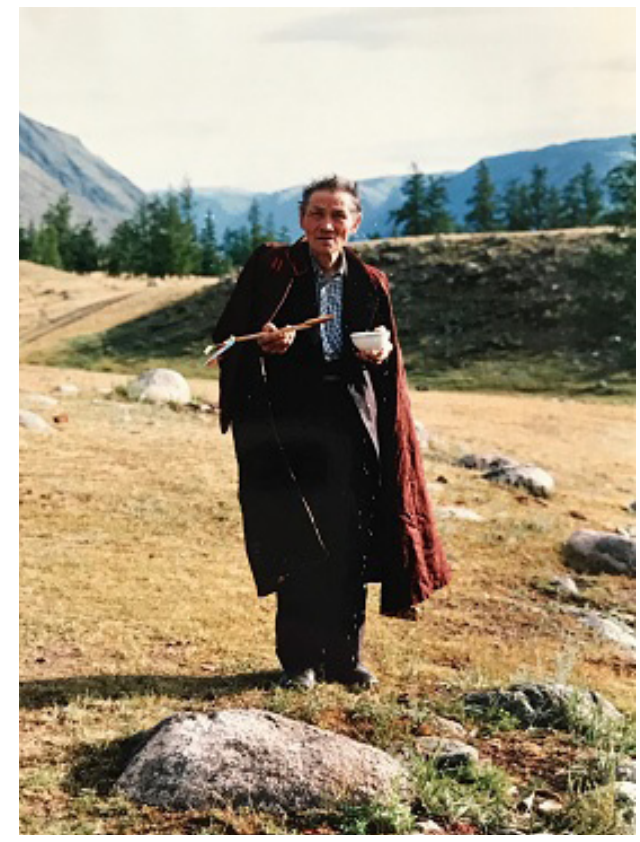

Фото 3. Балган Кужугет совершает совершает обряд кормления духов, Кара-Холь, Бай-Тайга, 1992 год. Фото Максима Шапошникова. Foto 3. Balgan Kuzhuget performs the offering to spirits of the taiga, Kara-Khol, Bai-Taiga, 1992. Photo by Maxim Chapochnikov ниях, в которых совместная игра сложных ритмов и речитатив алгышей вряд ли возможны.

Ооржак Хунаштар-оол показался мне при встрече человеком благодушным и размеренным. Он умел четко и тонко нюансировать мелодии обертонов и разнообразные эффекты, имел свой очень размеренный темп. Он как бы утверждал каждую ноту, выдувая во время пения сверкающий «кувшин» хоомея, существовавший пока продолжался ручей его дыхания. Хунаштар-оол обладал редким многогранным даром. Его репертуар был необъятным. Во время записи он продемонстрировал несколько индивидуальных стилей, в частности, думчук сыгыды (носовой сыгыт). Его игра на хомусе, его пение - не 
просто образцы высочайшего мастерства, но и отображают ту самую народную душу, которую невозможно сформулировать иными способами.

Эти, на первый взгляд, простые люди вызывали во мне восхищение и глубокое уважение.

Очень искусственно на этом фоне воспринимались советские обработки народной музыки с их оркестровыми аранжировками и переделанными инструментами.

Симпозиум 1992 г. стал переломным моментом, отправной точкой изменений в тувинской музыке, которые произросли на почве стремительного развития свободного рынка на территории бывшего СССР.

\section{Вхождение тувинской музыки в World Music}

Как это бывает с модами на определенные стили традиционной музыки, внимание рыночного интереса к хоомею пришел извне. В 1987-1988 г. американским этномузыковедом Тедом Левиным совместно с 3. К. Кыргыс были проведены полевые записи для выпуска диска с сугубо этнографическим материалом «Tuva: Voices from the Center of Asia» (Smithsonian Folkways SFW40017, 1990).

После пластинок советского периода это издание было первой серьезной работой по собиранию и изданию тувинского фольклора. Интерес со стороны академического американского издателя пришелся на тот же период, когда Зоя Кыргыс и Геннадий Тумат взялись за создание этнографического ансамбля «Тыва», что стало важным событием для самой Тувы, где культурное самоопределение ждало момента вырваться на свободу.

В состав ансамбля вошел цвет молодых талантливых исполнителей Тувы, вышедших их разных районов и хорошо владевших разными стилями хоомея и инструментальной музыки. В него вошли Тумат Геннадий, Кайгал-оол Ховалыг, Конгар-оол Ондар, Анатолий Куулар и другие. Музыкальная программа, дополненная играми, ламаистским и охотничьим фольклором, шаманским танцем, была составлена по принципу этнографического дивертисмента, с целью показать все разнообразие в короткое время концертного выступления. И это было именно то, чего людям не хватало в тот момент и в Туве и за ее пределами. Люди оценили чистое, «свое», неприукрашенное корневое звучание. Для тувинцев такой ансамбль был в новинку, но был принят как долгожданный, свой из повседневной жизни.

И это творчество засверкало вдруг в свете софитов без стеснения показаться отсталым. Для советских реалий это был вполне авангардный проект, а на Западе он был воспринят как обогащенный кислородом глоток свежего воздуха из страны с таинственным ореолом Шамбалы. 
Выпуск диска ансамбля «Тыва» в Нидерландах «The Tuva Ensemble - Voices From The Land Of The Eagles» (PAN 2005CD, 1991) и проведение заграничных гастролей оказали решающий толчок к всемирной известности тувинского горлового пения и его последующей монетизации как коммерческого продукта. Это был вполне логичный ход событий.

Резкий рост интереса к феномену World Music ознаменовался знаковым интересом к феномену горлового пения и обертонной музыки. Здесь мы не будем углубляться в подробности, заметим только некоторые факты, важные для понимания роли тувинской музыки в этом процессе (и того, каким трансформациям она сама и подверглась).

Ансамбль «Тыва» был по советским масштабам небольшим коллективом, состоящим всего из 10-12 человек. Однако для западного рынка, куда в конечном итоге была направлена коммерческая деятельность ансамбля, эта формула работала лишь короткое время и вскоре оказалась нерентабельной.

В отличие от этнографического альбома Т. Левина, который был собран по районам и равномерно вмещал и самодеятельных и профессиональных исполнителей, оба голландские диска ансамбля «Тыва» состоят из тщательно разученных профессиональных исполнений музыки разных жанров и регионов Тувы. Оба диска выпущены в этнической серии и претендут на этномузыкальную достоверность, что они вполне оправдывают. Аутентичность была самоцелью Геннадия Тумата, хотя ансамбль еще носил многие черты советской манеры презентации и аранжировки.

В составе были такие творчески сильные и страстные музыканты как Тумат Геннадий, Конгар-оол Ондар, Кайгал-оол Ховалыг, Анатолий Куулар, которым скоро стало тесно в составе сводного ансамбля. Чисто «советским» недостатком в подходе ансамбля «Тыва» было затенение индивидуальности исполнителей. Они были как бы послами культуры. Их задачей было показать черты своего народа. Но как и слушателям, так и самим исполнителям требовался более личный контакт.

Предприимчивые единицы быстро выделились из «тела» ансамбля. Так, «отпочковались» солисты Геннадий Тумат (он основал свой Овюрский состав «Ай-Херел»), Конгар-оол Ондар, ушедший в соло карьеру, Кайгал-оол Ховалыг, ставший лицом ансамбля «Хун-Хурту» и иконой нового периода развития тувинской музыки.

Первый альбом «Хун-Хурту» был выпущен в 1993 г. известной Американской фирмой Shanachie. Группу в тот момент курировал Т. Левин, который хорошо ориентировался как в научной ценности материала, так и в рыночном потенциале тувинской музыки. Это было попадание в десятку американского, да и мирового рынка World Music. 
К этому моменту развитие тувинской музыки уже стало тесно связано с западным музыкальным рынком. Два диска ансамбля «Тыва» оказались наиболее продаваемыми из каталога нидерладского Pan Records (по утверждению владельца этой студии Бернарда Клейкампа в личной беседе). Кайгал-оол Ховалыг, братья Александр и Саян Бапа, Анатолий Куулар создали форматную группу, с которой было удобно и недорого ездить на гастроли. Уже поиграв вместе в эстрадном ансамбле «Аян», имея наброски работы в жанре фьюжн («Кунгуртуг»), пообщавшись с известными поп-артистами в США (Frank Zappa и др.), музыканты создали свой собственный фолк-фьюжн на основе тувинской традиционной музыки. Они скрупулезно отобрали песенный репертуар и сделали первые оригинальные аранжировки тувинских песен для игила, гитары, дошпулуура, бызаанчи, перкуссий с добавлением аутентичных звуков. Под общим руководством Александра Бапа, музыканты отошли от тогда еще успешной, но тесной идиомы этнографического дивертисмента. Они создали свежую аранжировку тувинских песен, хорошо продумав контекст полнометражного концертного исполнения. «Хун-Хурту» ввели аранжировку традиционных инструментов, которая не искажала традиционное звучание по-советски, а посвоему обогащала и конденсировала его.

«Хун-Хурту» стали творчески использовать возможности усиления и звуковых эффектов. Они интегрировали шумовые инструменты в нарратив музыкальных пьес, адаптировали звукоидеалы тувинцев для «аутсайдеров» своей культуры. Гармонично чередуя ансамблевые аранжировки с более традиционными соло номерами, «Хун-Хурту» создали цельную концертную программу, которая не только блистала этнографической экзотикой, но и позволяла слушателям выйти на более доступный, персональный уровень общения с музыкантами.

Интерпретация песни «Межегей» из первого альбома «Хун-Хурту» - это один из примеров такой аранжировки. Каргыраа в исполнении Альберта Кувезина, который одно время выступал в составе группы, по рок-бардовски гармонично ложится на гитарную аранжировку. Вокал Кайгал-оола Ховалыга обогащен эффектом, создающим ощущение пения задом наперед, типичным для психоделического фолк-рока. И, хотя пение Альберта совсем нельзя назвать классически традиционным, эта аранжировка стала стандартом в глобальном восприятии тувинского репертуара, а разработанная «Хун-Хурту» формула стала формулой успеха.

После менее одного года участия в группе «Хун-Хурту» Альберт создал группу «Ят-ха», попробовав сначала силы с московским электронщиком Иваном Соколовским. «Ят-ха» была более популярна среди рок и панк ориентированной публики. После громкого ухода из «Хун-Хурту» Александр Бапа продолжил воплощать свои продюсерские идеи и создал группу «Чиргилчин», состоявшую из таких талатливых музыкантов как Игорь Кошкендей и Ондар Монгун-оол. 


\section{Тувинские звезды World Music}

Тувинская музыка сделалась доступной значительно более широкому кругу слушателей. Были другие проекты, которые пытались разработать похожую идею (“Shu-de”), но они не обладали видением и целостностью «Хун-Хурту».

С середины 1990-х годов члены группы «Хун-Хурту» встали в ряд с другими звездными феноменами World Music, стали знаком времени, внеся свой вклад в формирование формата потребления этнически заправленной популярной музыки. Этот состав выгодно зазвучал в концертном усилении. Мне запомнилось, как уже в 2000-х годах Александр Чепарухин (тогда менеджер «Хун-Хурту») после концерта в Екатеринбурге, куда была привезена специальная аудиосистема, выразил свой восторг звуковыми достижениями группы и говорил: «Теперь они звучат как Пинк Флойд!»

Высокая музыкальная чувствительность Кайгал-оола и его коллег, знание тувинского фольклора, упорство и умение работать - все это помогло им создать выразительный репертуар, уникальное звучание, и, что еще более впечатляет, продержаться в переменчивом мире музыкального бизнеса и сохранить свой статус культовой группы на долгие годы. Эффект новизны - один из важнейших факторов успеха в музыкальном бизнесе. Сегодня в глобализованном мире World Music эффект новизны достигается не столько за счет открытия новых культур («все уже открыто»), сколько за счет коллабораций, создания коктейля из разных музыкальных культур по индивидуальному рецепту.

World Music Fusion - это живой и очень интересный процесс миропознания через музыку. К сожалению, в этом жанре часто процветает некомпетентность и банальность. Проекты слишком скоропостижны и не позволяют углубиться в материал, становятся полем проявления индивидуальных «эго» профессиональных музыкантов и композиторов, но не создают новой долговременной ценности. Это касается не только поп-музыки, но и джаза и современной классики. Поверхностные и конфузные, на мой взгляд, музыкальные смеси часто принимаются как данное. Здесь можно вспомнить об экологии музыки, но это тема для отдельного разговора.

Процесс создания рецептов коктейлея World Music Fusion особенно усилился с развитием интернета и таких каналов, как Youtube, но время жизни нового тренда значительно сократилось относительно 1990-х годов.

«Хун-Хурту», будучи феноменом глобализованного музыкального рынка, должны были считаться с этим процессом. При всей своеобразности и самодостаточности тувинской музыки, «Хун-Хурту» успешно участвовали в десятках коллабораций с музыкантами самых разных жанров - от классики (Chronos Quartet) до фольклора (Angelite) и электроники (Samsonov, Carmen Rizzo). Многие из них стали образцами World Music. 
«Хун-Хурту» функционирует в жанре популярной музыки (частью которой является World Music Fusion), умело используя традиционный материал. Назвать творчество «Хун-Хурту» традиционной музыкой, на мой взгляд, некорректно. Первые альбомы группы, спродюсированные с участием Саши Бапа создали новый стандарт аранжировки и манеры исполнения тувинских песен. Музыкальный талант Кайгал-оола Ховалыга и его коллег, хороший маркетинг помогли создать непоколебимо стойкий продукт, который с одинаковым успехом потребляется за границей и в самой Туве.

Феномен World Music питается традиционной и этнической музыкой, но ею не является. Отсюда размытость термина и множество попыток назвать разные проявления этого феномена - этно, этнобит, World Beat, Neo Folk и т. д. Формат группы из 4-х человек - это рок и фолк формат для небольшой сцены. Групповое исполнение не характерно для традиционной тувинской музыки, не говоря уже об аранжировке для гитары, перкуссии, и других инструментов.

Программа в 1-1,5 часа покрывает разнообразие стилей, региональных и жанровых номеров, являет собой авторский концентрат традиционной музыки, собранной по всей Туве и от оригинальных исполнителей. Дивертисмент - обязательная уступка слушателю, который не знает языка и слушает относительно поверхностно. Для традиционных мастеров было характерно исполнение нескольких или даже всего одного коронного номера. В концертную же программу должен быть упакован целый запас песен. Заметим, что в ансамбле «Тыва» Кайгал-оол исполнял именно свои коронные номера - узун хоюг на игиле и разные стили хоомея. Такие песни, как «Плач сироты» и др., я тоже назвал бы песнями Кайгал-оола, настолько сильно они звучат в его интерпретации, хотя изначально это чисто народные песни.

Усиленное звучание, особенно усиление голоса, использование эффектов и мониторинга, меняют манеру исполнения.

Еще можем отметить высокий профессионализм исполнения. Народные исполнители могли исполнять с шероховатостями, нестроем, это принималось как должное. Профессионалы отрабатывают технику игры и настраивают инструменты по тьюнерам. При игре с западными музыкантами или нетрадицонными инструментами тувинские музыканты подстраивают свои инструменты на общепринятую западную частоту $440 \mathrm{HZ}$, тогда как традиционное исполнение тяготеет к 432-435 HZ.

Создание репертуара, запись и выпуск альбомов, радио и тв интервью проводятся в близком сотрудничестве с коммерческим директором, продюсером, издателем, агентом, которые функционируют по законам музыкального рынка.

Эти особенности так или иначе проявляются на записях или концертах группы, которые давно стали образцом исполнения тувинской музыки для молодежи. Взять, например, каргыраа Кувезина, который стал новым шаблоном в 
«этно», тогда как его каргыраа имеет мало характеристик филигранного традиционнаго каргыраа.

Вряд ли мы увидим в ближайшее время новых тувинских звезд мирового значения, подобных «Хун-Хурту». Рынок имеет определенную вместительность, и тувинская музыка уже заняла свой обьем на этом рынке. как известно, Боливар не выдержит двоих. Хотя претенденты на их место появляются регулярно, например, китайско-монгольская группа «Хангай».

Ценность тувинской музыки не столько в звездах, покоривших небосклон западного рынка, сколько в образовании стабильного сообщества людей, вдохновленных этой музыкой и культурой, ищущих новых путей эстетического и духовного мировосприятия.

Активность этого очень интернационального сообщества можно проследить в группах в социальных сетях и блогах.

\section{Тувинская музыка в Туве и мире сегодня}

Итак, к середине 1990-х годов интерес к аутентичному фольклору поутих по той простой причине, что аутентичный фольклор не есть рыночный продукт. Феномен World Music как губка впитал в себя элеметы аутентики и переработал его во многчисленные фьюжновые проекты. Истинный фольклор привязан к образу жизни и ландшафту. После кратковременной отработки ансамблем «Тыва», там он и остался, где был - в Бай-Тайге, Монгун-Тайге, Овюре, ДзунХемчике и Сут-Холе. Такие сильные исполнители как Андрей Опей и Герман Куулар не стали межународными звездами и живут в районах, обучая молодежь азам своей культуры.

Множество талантливых коллективов и солистов проделали свой сложный путь в нахождении своего сценического образа и репертуара, стали в той или иной степени известными. Сегодня Тува имеет свои рок-группы, авангардные, женские и т. д. Некоторые стараются быть пуристами в традиционной стилистике исполнения (например, Чодураа Тумат, хотя с другой стороны, ее работа несколько противоречит общепринятому мнению об исполнении хоомея женщинами), некоторые создают свою музыку, вдохновляясь традицией, в большей или меньшей степени опираясь на нее (Саинхо Намчылак, Гендос в авангардной сфере, Станислав Ириль в поп-музыке, «Чиргилчин», «Хун-Хурту», «Алаш», «Хартыга», Радик Тюлюш в фолк-роке, по-своему уникальные Национальный оркестр Тувы и Духовой оркестр Правительства Республики Тыва). Примером открытости тувинцев к коллаборациям и неожиданным решениям является ставшая традицией совместная работа Духового оркестра Демира Тюлюша и культовой джазовой группы из США Sun Ra. Возникли женские группы, которые создали свой женский репертуар (Надежда Куулар, «Тыва кызы», «Эзенги», «Угулза»). 
Еще 25 лет назад эта музыка была известна лишь элитарным искателям музыкальной экзотики, а сегодня горловое пение стало востребованным видом музыкального искусства. Записи ансамбля «Тыва», групп «Хун-Хурту», «Чиргилчин», «Ят-ха», а также Конгар-оола Ондара, их коллабораций с нетувинскими артистами распространились по всему миру и стали легкодоступны по Интернету.

Музыка этих групп привлекла сотни тысяч поклонников. Манера исполнения и аранжировка тувинских песен этих групп создала представление о тувинской музыке, создала первозданное восприятие манеры исплнения, аранжировок и техники пения. Тот же процесс произошел в самой Туве, где престиж групп, добившихся успеха и звездного статуса за пределами Тувы, распространение дисков и Интернет, сыграли решающую роль в выборе образцов для подражания молодого поколения. Тот факт, что естественный способ обучения хоомею - подражание, а не посещение музыкальной школы, сыграл на руку этому процессу. Это значит, что в процессе глобализации и доступности информации, выбор в процессе «преемственности» падает на успешные рыночные образцы, а не на выбор мастера, хотя определенная корреляция между коммерческим успехом и мастерством, конечно существует.

Интернет обладает особым ощущением времени. Как архив информации Интернет содержит обширные данные из разных уголков времени и пространства, находится в некоем безвременьи. Здесь можно оказаться в дальних уголках истории и получить актуальнейшую информацию. Интернет виртуально уничтожает границы и различия. Передача информации происходит молнеиносно и создает иллюзию реального времени.

Тысячи людей притягиваются к кажущейся простой технике и простодушию тувинцев, стараются научиться искусству хоомея по интернетным курсам и сами, недолго думая, загружают свои самодельные видеокурсы и блоги для всеобщего потребления. (Например, фолк на Tuva Music Recordings VK, поп на Tuva Music Style VK, солидный проект Chaa Records на Facebook). Tе, у кого есть средства, приезжают в Туву и получают уроки у местных хоомейжи. Сотни тувинских мальчишек, воодушевляясь успехом звезд, и будучи от природы музыкальными, копируют стиль исполнения кумиров. Интуитивно разработанные А. Бапа и А. Кувезиным форматы групп и тип аранжировки стали стандартом и подверглись массовому копированию с небольшими отклонениями. Значительно вырос сценический профессионализм тувинских музыкантов.

Групповое исполнение, которое мне довелось услышать в Туве в начале 1990-х годов, было зачастую нестройным. Горловики с дошпулуурами пели в унисон или по очереди, лишь усиливая общее звучание совместной игрой. Сегодня тувинцы настроили свой слух под цифровые камертоны и игру на хорошо настроенных инструментах. Вряд ли сегодня в Туве услышишь исполнение в духе Сундукая с его условно насторенным дошпулууром. 
C профессиональной аранжировкой народной музыки мы были знакомы еще в советское время в форме пафосных оркестров с трансформированным под симфонический оркестр инструментарием.

«Хун-Хурту» предложили теплый демократический вариант, хорошо сохранивший черты традиционного исполнения. Но не будем забывать, что «Хун-Хурту» существовал во многом как экспортный проект для западного рынка. В родной Туве не было средств, чтобы поддержать группу такого уровня. Оказавшись по умолчанию новым послом тувинской культуры, он создал формат тувинской музыки, который соответствовал мировым стандартам, но не обязательно достоверно отражал все особенности тувинской музыки и ее существования.

Например, реконструкция использования ударных в ансамблевой игре заметно обогащает общее звучание на концерте, делает звучание близким к полному спектру рок-музыки («Хун-Хурту», «Чиргилчин», «Алаш», «Ят-ха»). Но как использовались перкуссии за пределами храмовой игры мы не знаем. Тем не менее использование перкуссии стало сегодня стандартом в ансамблях от фольклорной музыки.

В расшифровках советского этномузыковеда А. Н. Аксенова тувинская музыка демонстрирует наличие разнообразия ритмики и микроритмики, вариации микроладов. В групповой игре эти элементы могут привести к ощущению фальшивости звука и требуют особого внимания и мастерства. Современная групповая аранжировка тяготеет к упрощению деталей, к ритму 4/4, характерному для поп-музыки.

Члены группы «Хун-Хурту» стараются не упустить особенности традиционного интонирования, хотя в рамках их формата это задача крайне сложная.

Действие «нормализации» за счет Интернета и музыкального рынка можно проследить на примере распространения тувинского хоомея так же и не в контрастной западной среде, а среди «своих». Бум возвращения к традиционным корням в середине 1990-х годов вызвал выдвижение таких артистов, как ансамбли «Сабчилар» из Хакасии, «Алтай Кай» из Республики Алтай, Хосоо и «Egschiglen» из Монголии, Намгар из Бурятии, «Окна Цаган Сам» из Калмыкии, Едил Хуссаинов из Казахстана и др.

Еще в начале 1990-х годов мне не доводилось встречать такое широкое распространение жанров горлового пения и разнообразия обертоновой музыки из этих регионов. Так или иначе в творчестве этих артистов мы слышим отголоски тувинских техник пения, интонирования и даже мелодики.

Распространение звуконосителей, в особенности тувинской музыки, позволило мызыкантам Саяно-Алтая и Центральной Азии заново открыть забытые жанры собственной традиции. И что здесь свое, а что заимствовано - это вопрос актуальный для этномузыковедов, а не для продюсеров фолк групп. Время 
научно обоснованного подхода к репертуару закончилось к середине в 1990-х. Сегодня речь идет о яркости индивидуальных исполнителей, сценической аранжировки, яркости костюмов, покорении слушателей и, в конце концов, о конкуренции. А законы бизнеса, как известно, жестоки.

Таким образом происходит процесс нивелирования индивидуальности, самостоятельности музыкального мышления, умения искать вдохновение во внутренней и внешней природе, глубоко философского взгляда на музыку и жизнь, не ограниченного чьим-то успехом или доходом - характеристики, так присущие ушедшим мастерам.

Вспомнить здесь как пример неформатного самостийного подхода к творчеству участие Ойдупы в телешоу «Минута славы». Можно подумать, что Владимир решил захватить мир и потерял голову от амбиций, пойдя на участие в такой одиозной программе. Но я с этим не согласен. Ойдупаа спел одну из своих коронных песен. Сочетание горлового пения и баяна член жюри назвал неблагозвучным. После того, как его выступление сурово «опустили», этот отсидевший в тюрьмах шофер и фрезеровщик, спокойно дал взвешенный комментарий об отсутствии у жюри музыкального образования. С чем мы полностью согласны. Возможно, если бы Ойдупаа сыграл «Лебедя» Сен-Санса, то жюри было бы в восторге.

Ойдупаа опробовал мир поп-культуры на собственном опыте и дал ему адекватную оценку.

\section{Заключение}

В 1960-х и 1970-х годах тувинская музыка была достоянием элитарных исследователей в этномузыковедении. Музыковеды В. Шуров и И. А. Богданов проделали невероятно важную работу по публикации тувинской музыки, «зарыли» клад, который был обнаружен в подходящее время и стал базой для знакомства с традиционной музыкой как в самой Туве, так и по всему миру. (Как Шуров, так и Богданов были собирателями и практиками в музыке, их интерес не был только исследовательским-теоретическим. Шуров имел свой собственный хор, Богданов писал авангадную электронную музыку. Богданов подготовил несколько очень важных изданий Сибирского фольклора. Среди них абсолютно уникальный двойной альбом нганасанской шаманской музыки. На базе собранных Богдановым материалов и интервью с ним я делал радиопрограмму для нидерландского радио VPRO “De Wandelende Tak”).

С начала 1990-х годов тувинская музыка ворвалась в мировое сознание наподобие монгольского нашествия. Очевиден глобальный успех тувинской музыки на мировом музыкальном рынке, хотя и нишевой. Этот рынок слишком консервативен и поверхностен для такой специфической музыки. Были попыт- 
ки продвинутых мэтров поп музыки представить хоомей более широкой аудитории: Peter Gabriel выпустил диск недолгосрочной группы «Шу-де» на его лэйбле Real World, группа Massive Attack вместе с рэппером Tricky использовали фрагмент записи каргыраа в Karmacoma (песня достигла высоких позиций в чартах), коллаборация «Хун-Хурту» с Frank Zappa, Carmen Rizzo и саундтрэк для фильма Geronimo c Ry Cooder, совсем свежее участие Радика Тюлюша в звуковой дорожке в телесериале Fargo - это скромные достижения на большом коммерческом рынке.

Однако звуки горлового пения очаровывали более восприимчивую публику. Люди, интересующиеся звуком, экспериментами, культурой, мифологией, этническими знаниями, нью эйджем, шаманизмом, отношениями человека с природой и ладшафтом, возможностями духовного развития человека через музыку неизменно интересовались тувинской музыкой. Т. е. особенную роль тувинская музыка играла и продолжает играть для тех, кто относится к музыке не как потребители, но сознательно слушают или создают свою музыку, отводят ей особую роль, как инструменту мировосприятия.

Далеко не всегда этот интерес глубокий и адекватный. Но не в этом дело. Важно то, что тувинская музыка дала десяткам тысяч людей пищу для вдохновения, развития и эксперимента. Иногда в виде эзотерического пения для лечения комнатных растений, иногда в виде концептуальной современной оперы, или трансовой музыки, исполняемой диджеями в Гоа для подпитанной LSD молодежи. Иногда в виде откровения и прозрения у тех, кто занимается развитием возможностей человеческого голоса.

Однако при этом неизбежен процесс нормализации восприятия тувинской музыки внешним миром. Таинственность и загадачность сибирского народа уже не так задевает объевшегося интернетными взрывами глобального потребителя глобализованной культуры. Глобализованный мир дает доступ к информации, помогает установить связи, немыслимые еще двадцать лет назад. Негативная сторона этого - стандартизация культуры и невилирования различий в технократически глобалозованном мире. Это сильно влияет на музыкальную культуры Тувы, единственным экспортом которой является музыка (и, в какойто степени, шаманизм).

С распространением записей, созданием курсов и школ хоомея молодежь увлеклась техникой исполнения и внешними эффектами, тем что хорошо смотрится на сцене или на видео. Очевидно меньше мы видим глубину и созерцание природы, которое так характерно для традиционной тувинской манеры исполнения. Для традиционных тувинцев характерна сдержанность и интравертнсть исполнения, отличная от, например, экстравертной монгольской.

Для тувинцев популярность хоомея сыграла роль особой важности, как никакой другой природный или культурный ресурс, какими богата Тува. Хоомей 
обрел почти мифическую репутацию, попадая в жанры от голосовой акробатики до эзотерического пения, в поп, рок и нео-классическую музыку. Он вывел неведомую Туву на уровень мирового мифа XX-го века.

Тува шагает в ногу со временем и тоже вошла в эпоху Auto Tune, или автоматической коррекции высоты звука голоса или инструмента высоты звука, помогающей искусственно избежать ошибок и отклонений в процессе звукозаписи, наподобие подчистки фотографий в Photoshop. Давление идеологии советского периода сменилось стрессом и требовательностью свободного рынка и всеобщей нормализации культуры.

Как то, так и другое не ложится гармонично на традиционное мировоззрение тувинцев.

Идея Auto Tune противоречит философии тувинской музыки.

Как это противоречие разрешится - мы увидим в ближайшие 10-15 лет.

Дата поступления: 10.05.2017 2.

\section{Для цитирования:}

Шапошников М. В. Тувинская музыка и World Music [Электронный ресурс] // Новые исследования Тувы. 2017, № 2. URL: https://nit.tuva.asia/nit/article/view/712 (дата обращения: ...). DOI: 10.25178/nit.2017.2.5

\section{For citation:}

Chaposhnikov M. V. Tuvan music and World Music. The New Research of Tuva, 2017, no. 2 [on-line] Available at: https://nit.tuva.asia/nit/article/view/712 (accessed: ...). DOI: 10.25178/nit.2017.2.5 